\title{
THE MEANS OF PUBLIC INSTITUTIONS TO PROTECT THE SUBJECTS OF LAW AGAINST CRIME
}

\author{
R. ȘERBĂNESCU
}

\section{Robert ȘERBĂNESCU}

Faculty of Law and Administrative Sciences, Law Department

Christian University “Dimitrie Cantemir”, Bucharest, Romania

*Correspondence: Robert Șerbănescu, Christian University „Dimitrie Cantemir”

No. 176 Splaiul Unirii St., Sector 3, Bucharest

Email: serbanescu.robert.2013@gmail.com

\section{ABSTRACT}

The article covers the means by which public instiutions protect the rights and freedoms of its citizens from the crime phenomenon. The main focus of the paperwork is represented by the analysis over three major sections: the fundamental law of Romania, the Criminal Code of Romania and the legal norms present at the level of the European Union. Subsequently, conclusions will be provided at the end in order to draw out the essence of the research.

KEY WORDS: Phenomenom, analysis, norms, institutions, crime

\section{INTRODUCTION}

The human being is a sociable form of existence, therefore it cannot live on its own, requiring the assistance of others in order to develop properly and to know true happiness. Since the early days of our species, we came in contact with each other and formed communities. The purpose of these social structures was to ensure the satisfaction of basic needs such as security, food and reproduction. Given their nature, humans have the tendency to evolve beyond the conditions of a certain moment. In the same manner, the group will follow in the footsteps of the members, becoming more complex with every new level reached. Throughout time tribes expanded into kingdoms,empires and states at the current stage.

States are an assembly of institutions meant to defend the citizens from exterior and interior threats through the mechanisms at their disposal.

\section{THE MOST IMPORTANT METHOD OF PROTECTION}

In any action taken with the objective to create a new domain or to lay the foundation of a structure, a central pillar is required in order to guide the next steps. This rule applies the same in the event that a new form of government is established. Such was the case in December 1989 when Romania, as a result of the Revolution, became a Semi-Prezidential Republic. In other words, our country transitioned from a totalitarian form of state to a democratic one.

The first and most important brick placed on the path to an authentic republic was at that time the Constitution of Romania adopted in 1991.

From a legal perspective, the Constitution of Romania represents the main law by which society is governed. The constitutional stipulations possess the highest law force, all the other legal norms accepted and put into practice must follow their guidelines. The supremacy of the constitutional norms is assured by the constitutional control ${ }^{1}$.

\footnotetext{
${ }^{1}$ Ş.Deaconu, Drept Constituțional, ”C.H. Beck” Publishing House, Bucharest, 2011, p. 16.
} 


\section{Robert Șerbănescu}

The fundamental law contains the basic reglementations of the social reports which take place in our country and with other states or internationally recognized institutions. In this manner, the Constitution names the three powers of the state (The Executive Power, The Legislative Power and The Judicial Power) alongside their duties, the freedoms and obligations of the citizens, the procedures by which new laws are adopted and the position of the country on the international level.

Due to the importance of the constitutional regulations and the supreme authority they hold, we can say that, by admitting the rights and freedoms of the individuals in this context, the first layout of protection againts criminality is set in place.

To be in the presence of a crime event two conditions must be met, as per the legal interpretation:

Firstly, a legally protected and recognized social norm must be affected. This is a general requirement applicable to various cases.The difference comes from the second component which is that the illegal activity presents danger to the right to live or the physical integrity of the victim.

The possibility to live and have a functional body and/or mind are the main roots by which a person can exercise their other freedoms. Knowing this infomation, it is only natural and logic that the Constitution would include these basic rights in its texts, therefore the basic law dictates that ,the right to live as well as the right to physical and mental integrity are guaranteed"2.

It is also assured that living is done in proper conditions with no negative impact from any external factors designed to affect in a bad manner the organism or menthal health of a citizen, such would be the case with torture and inhuman treatment, both being banned ${ }^{3}$.

Some countries have the legal option to condemn their criminals to death, for example in the United States of America. However, in Romania the capital punishment is prohibited on a constitutional level ${ }^{4}$. This can serve as proof that the legislator looked for an extra way to assure the right to exist even to convicts. Given time and proper assistance, any indiviual can repent for their actions and practice their rights without having to damage the liberty of others. Also, the structures assigned to judge and provide solutions to criminal cases are stoped from committing a crime in the event that someone would be convicted to death based on insufficient or false proof.

\section{CRIMINAL LAW AND THE COERCIVE FORCE OF THE STATE}

As shown in the previous chapter, the Constitution represents the central point from which all the other laws are derived. The most important type of regulations detailed and expanded in accordance with the primary norms for this article are the ones available in the Criminal Law area.

In order to understand the important role that these type of stipulations have in the process of protection againts criminality, we require a minimum imformation about public institutions, criminal law and the coercive force of the state.

The Executive Power is held by the Government, this structure is divided into several ministries such as the Ministry of Foreign Affairs, Ministry of National Defence, Ministry of National Education, Ministry of Tourism, Ministry of Internal Affairs, Ministry of Justice, Public Ministry and so on. These are central public authorities with different public institutions subordinated. Based on the data shared, we can define a public institution as a

\footnotetext{
${ }^{2}$ Constituția României. Convenția Europeană a Drepturilor Omului. Carta Drepturilor Fundamentale ale Uniunii Europene, "ROSETTI INTERNATIONAL" Publishing House, Bucharest, 2018, p. 18, Title II, Chapter II, Art. 22, alin (1).

${ }^{3}$ Ibidem, alin. (2).

${ }^{4}$ Ibidem, alin. (3).
} 
THE MEANS OF PUBLIC INSTITUTIONS

TO PROTECT THE SUBJECTS OF LAW AGAINST CRIME

subsidiary structure of a central or local public authority, with its costs covered from public funds 5 .

The Criminal Law is composed of the totality of legal norms ment to protect the values of a society by setting several activities as crimes and sanctions for commiting them. The main two goals of this branch of law is to either prevent incriminated behaviours or to punish those already consumed ${ }^{6}$.

Regulations of the criminal law reside in the Criminal Code of Romania and other special laws. The public institutions which ensure that these reglementations are followed and applied if necessary are the Police (part of the Ministry of Internal Affairs), the courts (part of the Ministry of Justice) and the Prosecutor's Offices attached to them (part of the Public Ministry).

It is relevant to mention that the Police and the Prosecutor`s Offices are components of the Executive Power, they represent the state in criminal cases as accusers, seeking to prove to the judges that an illegal deed has been completed. On the other hand, as mentioned in the current legislation, the courts constitute the Judicial Power ${ }^{7}$, making sure that justice is served if someone is found guilty. Even if they are affiliated with the Ministry of Justice, the courts are independent and make decisions in accordance to the evidence provided and with no external interferences.

As for the coercive force of the state it can be explained as that authority granted by a law to a public organism, such as the police or the judicial bodies, to uphold a subject of the law for his illegal behaviour by restricting some of his rights, questioning him in order to find evidence to support the accusations or to make him execute the sentence as a result of a definitive and irrevocable decision offered by the court.

Three principal means serve as preservation againts crime, reassuring the right to live and the menthal and psysical integrity of the persons, within the sphere of the Criminal Law. These are the activity of the police, the prosecution procedures and the cases presented to judges.

First of all, the police, as determined by the current law based on which their atributes are listed, have the responsibility of protecting the lives alongside the integrities of the members from the community ${ }^{8}$.

With this objective in mind, they are permitted to take all the necessary measures for maitaining the order and the public safety. Also, the representatives of the law can put into motion any legal act for the prevention and fighting againts the crime phenomenon and terorism ${ }^{9}$.

The police officers patrol the streets of a location day and night, they identify individuals who manifest suspicious conducts and question them. Also, they are called in when incriminated events are in place and help sustain the safety of everyone.

Secondly, prosecutors are the magistrates which act on behalf of the state as the accusing part and as investigators when a scene of a crime is reported. With reference to the Criminal Code, the prosecutor is the one in charge of coordinating the prosecution act, procedure which involves the gathering of evidence related to a criminal affair, the

\footnotetext{
${ }^{5}$ Dana Apostol Tofan, Drept Administrativ. Volumul I, "All Beck" Publishing House, Bucharest, 2003, p.6.

${ }^{6}$ C. Mitrache, Cr. Mitrache, Drept penal român. Partea Generală, "Universul Juridic" Publishing House, Bucharest, 2014, p. 22.

${ }^{7}$ Legea $n$ r. 304 din 28 iunie 2004 privind organizatia judiciară, publicată în M.Of. nr. 576/29 iun. 2004, repulicată în M.Of. nr. 827/13 sep. 2005,cu modificările și completările ulterioare, Title I, Chapter I, Art.1, alin. (1).

${ }^{8}$ Legea nr. 218 din 23 aprilie 2002 privind organizarea și funcționarea Poliției Române, publicată M.Of. nr. 305/9 mai. 2002, repulicată în M.Of. nr. 307/25 apr. 2014 cu modificările și completările ulterioare, Chapter III, Art. 26, alin. (1).

${ }^{9}$ Ibidem, alin. (2).
} 


\section{Robert Șerbănescu}

identification of the authors and the determination of ones criminal liability (necessary to know if the case will be sent in court or not $)^{10}$.

The law states that a prosecutor can start the prosecution either based on a criminal complain or by ex officio notification ${ }^{11}$.

Thirdly, when a criminal categorized act is consumed and the prosecutor has collected enough data to demonstrate the accusation, the case is debated in court where a decision will be made by the judges if the potential criminal is found guilty or not.

Due to the significance of their assignment, the judges must make sure that they have a clear representation of the events that took place. They will listen to both parties (accusation and defense) and they will also have to analyze and decide which proof is genue, relevant and can be taken into consideration. Also, the magistrates require to maintain the order in the court as well as an objective approach towards the case, personal feelings being left out of the decision. After a conclusion is drawn, the accused can be held responsible for the events or recognized as innocent.

In the event someone is presented as guilty, the judge will dictate a punishment to be applied in accordance with the law and through a definitive and irrevocable decision. The coercive force of the state will force the criminal to attend a correctional institution to repent for his actions (jail, prison) with a timeframe from several months to years, proportional with the form of the criminal act done. In this way, a toxic element is isolated from the other members of society so that their freedoms and rights are reassured and the social values are once more protected.

\section{COLLABORATION AGAINTS CRIME IN THE EUROPEAN UNION}

The European Union can be defined as a confederation of the states in Europe, its founding being based on several treaties, with the purpose to reach a superior level of coexistence between different populations, through collaboration an assistance in several domains such as security, economy, investments, trade, resources and law.

In the earliest days, the predecessors of the current EU were The European Community for Coal and Steel, The European Economic Community and The European Community for Atomic Energy.

Slowly but surely their ideas and actions expanded throughout the last century, gaining more members. Today the EU has a total of 28 states as members ${ }^{12}$.

Romania became a member of the European Union on the 1st of January 2007 assuming all the necessary obligations and benefiting from all the rights which come with this status.

By coming into this block, our country gained extra means of protection for its people versus crime, as an example we can provide the procedure of the european arrest warrant.

As stipulated by the current law, the european arrest warrant can be categorized as a decision made by a recognized judicial authority of a member state to have a certain individual arrested and brought back in his country by the other members, with the goal to start a prosecution procedure or either to send the case in court, as well as to execute a sentence $^{13}$.

It is well known that millions of romanian citizens work in other countries in the EU, therefore someone who comitted a crime and had decided to run in another state represents a danger to our countrymen abroad. With this line of thinking, the law system of Romania with

\footnotetext{
${ }^{10}$ Noul Cod Penal. Noul Cod de Procedură Penală, "Hamangiu" Publishing House, Bucharest, 2014 p.385, Title I, Chapter I, Art. 285 and 286, alin. (1).

${ }^{11}$ Ibidem, Art 288, alin. (1).

${ }^{12}$ A. Fuerea, Manualul Uniunii Europene. Ediția a V-a revăzută și adăugită după Tratatul de la Lisabona (2007/2009), ’Universul Juridic" Publishing House, Bucharest, 2011, pp. 14-31.

${ }^{13}$ Legea nr. 302 din 28 iunie 2004 privind cooperarea judiciară în materie penală publicată în M.Of. nr. 594/1 iul. 2004, reuplicată în M.Of. nr. 377/31 mai. 2011, M.Of. nr. $411 / 27$ mai. 2019 cu modificările și completările ulterioare, Title III, Chapter I, Art. 84, alin. (1).
} 
THE MEANS OF PUBLIC INSTITUTIONS

TO PROTECT THE SUBJECTS OF LAW AGAINST CRIME

the support from other nations can ensure that the problem is dealt with. Since we are part of a bigger community, this is also to protect the social values of the other members.

\section{CONCLUSIONS}

Based on the information given we can deduce that the most important and primary method by which the criminal current is minimized is to have the basic standards of a society recognized and guaranteed at its most important levels. This means that the Constitution is an undisputable statement, a core and the root for all the laws and procedures. It can be classified as a primary wall of defense.

The Criminal Law has a significant role to play in order to uphold the constitutional regulations with the work done by the police officers, prosecutors and judges.

In the era of globalization, fast processess and evolving technology, criminal cases tend also to improve, thus one state cannot fight this battle alone. The European Union ensures that international cooperation in the judicial matter is covered and that states are willing to share, assist and support each other.

\section{BIBLIOGRAPHY}

Consituția României. Convenția Europeană a Drepturilor Omului. Carta Drepturilor Fundamentale ale Uniunii Europene, "ROSETTI INTERNATIONAL" Publishing House, Bucharest, 2018;

Noul Cod Penal. Noul Cod de Procedură Penală, "Hamangiu" Publishing House, Bucharest, 2014;

Legea nr. 302 din 28 iunie 2004 privind cooperarea judiciară în materie penală publicată în M.Of. nr. 594/1 iul. 2004;

Legea nr. 304 din 28 iunie 2004 priving organizația judiciară, publicată în M.Of. nr. 576/29 iun. 2004;

Legea $n r .218$ din 23 aprilie 2002 privind organizarea și funcționarea Poliției Române, publicată M.Of. nr. 305/9 mai. 2002.

C. Mitrache, Cr. Mitrache, Drept penal român. Partea Generală, "Universul Juridic" Publishing House, Bucharest, 2014;

A. Fuerea, Manualul Uniunii Europene. Ediția a $V$-a revăzută și adăugită după Tratatul de la Lisabona (2007/2009), "Universul Juridic" Publishing House, Bucharest, 2011;

Ș. Deaconu, Drept Constituțional, "C.H. Beck" Publishing House, Bucharest, 2011;

Dana Apostol Tofan, Drept Administrativ. Volumul I, "All Beck" Publishing House, Bucharest, 2003. 